\author{
애기외톨개모자반 (Myagropsis yendoi) \\ 추출물의 항균활성 \\ 박나비·송유진·김꽃봉우리·이청조·정지연·곽지희 \\ 최문경·김민지·남기완 ${ }^{1} \cdot$ 안동현* \\ 부경대학교 식품공학과 / 식품연구소, ${ }^{1}$ 부경대학교 자원생물학과
}

\title{
Antimicrobial Activity of Myagropsis yendoi Extract
}

\author{
Na-Bi Park, Eu-Jin Song, Koth-Bong-Woo-Ri Kim, Chung-Jo Lee, \\ Ji-Yeon Jung, Ji-Hee Kwak, Moon-Kyoung Choi, Min-Ji Kim, \\ Ki-Wan Nam ${ }^{1}$ and Dong-Hyun Ahn* \\ Department of Food Science \& Technology / Institute of Food Science, \\ Pukyong National University, Busan 608-737, Korea \\ ${ }^{1}$ Department of Marine Biology, Pukyong National Univerisity, Busan 608-737, Korea
}

This study examined the antimicrobial activity of Myagropsis yendoi (MY). The antimicrobial activity of ethanol and aqueous MY extracts were measured using a paper disc assay. The MY ethanol extract had the best antimicrobial activity. It inhibited the growth of Candida tropicalis and Gram-positive bacteria such as Bacillus subtilis, Listeria innocua, L. monocytogenes, and Staphylococcus aureus at $4 \mathrm{mg} / \mathrm{mL}$. The minimum inhibitory concentration (MIC) of the MY ethanol extract ranged from 0.1 to $0.5 \%$. The MY ethanol extract inhibited the growth of B. subtilis and L. innocuaat concentrations of $0.15 \%$ and $0.1 \%$, respectively. The antimicrobial activity of the MY ethanol extract was not affected by heating at $121{ }^{\circ} \mathrm{C}$ for $15 \mathrm{~min}$ or $\mathrm{pH} \mathrm{2-10.} \mathrm{Therefore,} \mathrm{the} \mathrm{main} \mathrm{substances} \mathrm{responsible} \mathrm{for} \mathrm{the} \mathrm{antimicrobial} \mathrm{activity} \mathrm{of} \mathrm{the}$ MY ethanol extract are believed to be stable with changing heat and $\mathrm{pH}$.

Key words: Myagropsis yendoi, Antimicrobial activity, Food borne pathogens, Natural preservation

서 론

과학기술의 발달과 산업화에 의해 국민들의 소득이 증가됨 과 동시에 생활의 질적 수준이 높아지고, 국제 교류가 활발해 지면서 식생활 문화가 다양해지고 있다. 이로 인해 웰빙 식품 에 대한 선호가 높아지면서 식품의 오염 및 변질의 기회도 급증하고 있다 $(\mathrm{Kim}, 1997)$. 식품의 변질 및 부패는 물리·화학 적 및 미생물학적 요인에 의해 일어나지만, 그 중 미생물학적 인 요인에 의해 발생하는 경우가 대부분이다. 이러한 미생물 중에는 식품의 변질뿐만 아니라 식중독을 유발할 수 있는 병원성 세균도 포함되어 있다. 또한 지구온난화 등 기후 변화 와 외식 및 집단급식의 증가로 발생규모가 대단위인 경우가 많으며, 병원균뿐만 아니라 노로바이러스와 같은 사람과 사람 간의 전염성이 있는 병원체도 증가하고 있어 식중독이 식품산 업 및 공중위생 분야를 비롯해 사회적인 문제로 대두되고 있다 (Jo et al., 2009). 원인별로는 병원성 Escherichia coli, Salmonella sp., Staphylococcus aureus, Vibrio parahaemolyticus, Campylobacter jejuni, Clostridium perfringens 6종이 주요 세균성 식중독의 원인균이며, 2009년 식중독 발생 222건 중 원인체가 불명확한 것 94건을 제외하면 세균성 식중독이 주를 이루고 있다. 현재 이러한 식품 부패 및 식중독 관련 미생물의 증식을 효과적으 로 제어하기 위하여 가열, 초고압, 방사선 $\mathrm{PEF}$, 광펄스 등의

\footnotetext{
*Corresponding author: dhahn@pknu.ac.kr
}

물리적 처리 및 알코올, 염소, 과산화수소 등 화학적 방법을 주로 사용해오고 있다 (Kim et al., 2006). 특히 식품에 사용되고 있는 보존제들은 대부분 인공합성제로 그들의 안전성에 대한 문제들이 증가되고 있다 (Su et al., 2010). 합성보존제에 관한 안전성 문제로는 장기간 섭취 시 체내 축적으로 인한 만성독 성, 발암성, 돌연변이 유발성 및 내성균주의 출현 등이 보고되 고 있다 (Ferrand et al., 2000). 이로 인해 합성보존제에 대한 소비자들의 기피현상이 두드러지고 있으며, 식품산업계에서 도 합성보존제의 사용을 제한하려는 추세로 안전성이 확보된 천연 항균물질을 식품의 보존에 이용하고자 하는 연구를 많이 진행해오고 있다 (Kim et al., 2006). 일반적으로 오랫동안 사용 되어 안전성이 입증된 천연물을 그대로 사용하거나 추출하여 이용하는 경우 이들의 사용량은 규제하고 있지 않으며 미국에 서는 이를 generally recognized as safe (GRAS)로 분류하여 관리하고 있다 (Jung and Cho, 2003). 따라서 이들의 개발과 이용은 식품의 안전성에 대한 소비자들의 기피현상을 유발하 지 않으면서도 저장성 향상과 안전성 확보라는 견지에서 매우 중요하다고 볼 수 있다.

현재까지 천연 항균제 개발에 관한 연구로는 마늘 (Chung et al., 2003), 양파 (Sheo, 1999), 정향 (Lee et al., 2004), 계피 (Jeong et al., 1998) 등의 향신료나 목단피 (Hwang and Han, 2003), 단삼 (Mok et al., 1995), 상백피 (An et al., 1997), 강황 (Kim et al., 2000), 고삼 (Ahn et al., 1998) 등의 약용식물, 
이들의 정유성분 및 동물을 대상으로 이루어져 왔다. 최근에 는 육상의 동식물외에 항균활성을 비롯한 다양한 생리활성물 질의 새로운 자원으로써 해양 생물자원이 주목받고 있다. 특 히 해조류는 오랜 기간 식용으로 사용되어 안전성이 확보되었 으며, 최근 고지혈증 예방 (Awad et al., 2003), 항산화 (Iwashima et al., 2005), 항암 (Lee et al., 1992), 항염증 (Kim et al., 1997), 면역조절작용 (Liu et al., 1997) 및 항균작용 (Kuda et al., 2007) 등 다양한 생리활성물질을 함유하고 있는 것으로 알려져 있다. 현재까지 해조류로부터 알려진 항균물질로는 diterpene 및 triterpene계 화합물, 페놀류, tannin류 지방족 화합 물 및 함황화합물이 있다 (Kolanjinahan et al., 2009). 또한 홍조류의 빨간검둥이과 (Rhodomelaceae) 해조류로부터 분리 한 bromophenol (Choi et al., 2000), Sargassum sagamianum에서 분리된 Quinone류 (Horie et al., 2008), Sargassum macorcarpum 에서 분리한 Sargafuran (Yuto et al., 2009) 등이 보고되고 있다. 이들은 식품 부패 미생물에 대한 천연보존료로의 이용뿐만 아니라 피부질환 원인균으로 발생된 아토피, 여드름 등 피부 질환치료제로도 그 활용가능성이 매우 높다.

한편 애기외톨개모자반 (Myagropsis yendoi)은 갈조식물로 모자반속에 속하며, 우리나라 남해안과 제주해안 및 일본에 자생하고 있으나, 그 생리활성에 관한 연구는 전무한 실정이 다. 이에 본 연구에서는 애기외톨개모자반 추출물의 항균활성 을 조사하고, 나아가 천연보존료로의 사용 가능성에 대해 연 구하였다.

\section{재료 및 방법}

\section{실험재료}

본 연구에 사용된 애기외톨개모자반은 부산 기장에서 채취 하였으며, 담수로 깨끗이 세척하여 소금, 모래 및 착생 식물 등과 같은 이물질을 제거한 후 상온에서 건조시켜 분쇄한 다음 동결건조를 하여 $-20^{\circ} \mathrm{C}$ 에 보관하여 실험에 사용하였다.

Table 1. List of strains used for present experiments

\begin{tabular}{|c|c|c|c|}
\hline & Strains & Strains number & Media \\
\hline \multirow{8}{*}{ Bacteria } & Bacillus subtillis & KFCC 35421 & NB \\
\hline & Escherichia coli & ATCC 25922 & NB \\
\hline & Clostridium perfringens & KCTC 3269 & $\mathrm{RCM}$ \\
\hline & Listeria inoccua & ATCC 33090 & $\mathrm{BHI}$ \\
\hline & Listeria monocytogenes & KCTC 3569 & $\mathrm{BHI}$ \\
\hline & Salmonella typimurium & ATCC 14028 & NB \\
\hline & Serratia liquetaciens & KCTC 2825 & NB \\
\hline & Staphylococcus aureus & KCTC 6538 & NB \\
\hline \multirow{3}{*}{ Yeast } & Candida albicans & KCTC 7270 & YM \\
\hline & Candida tropicalis & KCTC 7901 & YM \\
\hline & Saccharomyces cerevisiae & KCTC 7905 & YM \\
\hline \multirow{2}{*}{ Mold } & Aspergillus niger & KCTC 6906 & PDB \\
\hline & Penicillium expansum & KCTC 6436 & PDB \\
\hline
\end{tabular}

\section{시험균주 및 배지}

실험에 사용된 균주와 각 균주의 배양 배지는 Table 1 과 같다. 시험 균주는 그람 양성균 5종 (Bacillus subtillis, Clostridium perfringens, Listeria inoccua, Listeria monocytogenes, Staphylococcus aureus) 그람 음성균 3종 (Escherichia coli, Salmonella typimurium, Serratia liquefaciens), 효모 3종 (Candida albicans, Candida tropicalis, Saccharomyces cerevisiae), 곰팡이 2종 (Aspergillus niger, Penicillium expansum)을 선정하여 사면 배지에 배양되어 있는 균주의 단일 집락을 일 백금이 취해 액체 배양하여 활성화시켜 실험에 사용하였다. Clostridium perfringens는 액체배지에 접종한 후 gas pak 및 anaerobic indicator (BBL Micobiology System, Cockeysville, MD, USA) 와 함께 혐기성 jar에 넣어 혐기성 상태를 유지하며 $37^{\circ} \mathrm{C}$ incubator (Dongwon Science Co., Busan, Korea)에서 24시간 동안 배양하여 사용하였으며, 이를 제외한 나머지 세균은 각 균주의 배양배지에 접종하여 $37^{\circ} \mathrm{C}$ 에서 24 시간 동안 배양한 후 사용하였다. 효모는 $25^{\circ} \mathrm{C}$ 에서 48 시간 배양하였으며, 곰팡 이는 실온에서 3-5일간 배양하여 포자를 형성시킨 후 사용하 였다. 시험 균주의 생육 배지로 nutrient broth $(\mathrm{NB})$ 는 Accumedia사 (Lansing, MI, USA)의 제품을 사용하였고 brain heart infusion (BHI), reinforced clostridial medium (RCM), potato dextrose broth (PDB), muller hinton broth (MHB)는 Difco 사 (Sparks, MD, USA)의 제품을 사용하였다. Yeast malt medium(YM)배지는 실험실에서 제조하여 사용하였다.

시료의 추출

건조 분쇄된 시료에 $94 \%$ ethanol 또는 물 10 배량을 가하여 실온에서 24 시간 동안 교반하며 추출하였다. 추출액을 원심분 리기 (UNION 32R, Hanil Co., Incheon, Korea)로 3000 rpm에서 10 분간 원심분리하여 상층액은 취하고 잔사는 이와 동일한 방법으로 2회 반복하여 추출하였다. 상층액을 모아 여과지 (Advance 5A, Tokyo, Japan)로 여과한 후, Rotary evaporator (RE200, Yamato Co., Tokyo, Japan)를 이용하여 감압 농축하였 다. 이 농축액을 $37^{\circ} \mathrm{C}$ 에서 건조시킨 후 $-20^{\circ} \mathrm{C}$ 에서 보관하여 사용하였다.

\section{Paper disc assay}

높이가 4-5 mm인 MHA (muller hinton agar) 평판 배지에 균액의 농도가 약 $10^{5}-10^{6} \mathrm{CFU}$ 가량 되도록 분주한 후 도말 삽으로 도말하였다. 지름이 $6 \mathrm{~mm}$ 인 멸균된 disc를 $\mathrm{MHA}$ 평판 배지 위에 고정시키고, $4 \mathrm{mg} / \mathrm{mL}$ 로 희석한 애기외톨개모자반 추출물을 $20 \mu \mathrm{L}$ 흡수시켰다. 이를 1시간 정도 확산시킨 후 $37^{\circ} \mathrm{C}$ incubator에서 24시간 배양하였다. 이때 혐기성 균주는 gas pak (BBL) 및 anaerobic indicator와 함께 혐기성 jar에 넣어 배양하였고, 효모는 확산 후 $25^{\circ} \mathrm{C}$ incubator에서 48 시간 배양하 였으며 곰팡이는 실온에서 3-5일 배양하였다. 배양 후 형성된 clear zone의 크기로 항균력을 판단하였다.

Minimum Inhibitory Concentration(MIC) 멸균 후 완전히 굳지 않은 $\mathrm{MHA}$ 배지에 $100 \mathrm{mg} / \mathrm{mL}$ 로 희석 
한 애기외톨개모자반 추출물을 원하는 최종농도에 맞춰 첨가 한 후, 시험 균주의 농도가 약 $10^{5}-10^{6} \mathrm{CFU} / \mathrm{g}$ 가량 되도록 접종하여 혼합하여 이를 평판에 분주하고 실온에서 굳혀, 3 $7^{\circ} \mathrm{C}$ incubator에서 24시간 배양하였다. 이때 혐기성 균주는 gas pak (BBL) 및 anaerobic indicator와 함께 혐기성 jar에 넣어 배양하였고, 효모는 $25^{\circ} \mathrm{C}$ incubator (Dongwon Science Co., Busan, Korea)에서 48시간 배양하였으며 곰팡이는 실온에서 3-5일 배양하였다. 배양 후 실체 현미경 상에서 균의 성장이 관찰되지 않은 평판의 농도를 최소저해농도 (MIC)로 하였다.

열 안정성

$4 \mathrm{mg} / \mathrm{mL}$ 농도로 희석한 시료를 $60^{\circ} \mathrm{C}$ 에서 10 분, 30 분 및 60 분, $80^{\circ} \mathrm{C}$ 및 $100^{\circ} \mathrm{C}$ 에서 10 분과 20 분, $121^{\circ} \mathrm{C}$ 에서 15 분간 열처 리한 후 급냉하였다. 이를 $4^{\circ} \mathrm{C}$ 에 보관하며 paper disc법으로 열처리에 의한 항균활성 변화를 측정하였다.

\section{$\mathrm{pH}$ 안정성}

$4 \mathrm{mg} / \mathrm{mL}$ 농도로 희석한 시료의 $\mathrm{pH}$ 를 $0.1 \mathrm{~N} \mathrm{NaOH}$ 와 0.1 $\mathrm{N} \mathrm{HCl}$ 을 이용하여 $2,4,6,8$ 및 10 으로 조절한 후 상온에서 24 시간 동안 방치하였다. 24시간 방치한 시료를 본래의 $\mathrm{pH}$ 로 중화시킨 후 paper disc법으로 $\mathrm{pH}$ 처리에 의한 항균활성 변화를 측정하였다.

\section{결과 및 고찰}

\section{애기외톨개모자반 추출물의 항균활성}

추출 용매에 따른 항균물질의 활성을 확인하기 위해서 애기 외톨개모자반을 에탄올과 물로 추출한 후 paper disc법을 이용 하여 그람 양성균 1 종과 그람 음성균 1 종에 대한 항균력을 측정하였다 (Table 2). 그 결과, 애기외톨개모자반 에탄올 추출 물의 그람 양성균에 대한 항균효과가 확인되었다. 반면, 애기외 톨개모자반 물 추출물은 항균효과를 나타내지 않았다. 이와 같은 결과는 지충이 추출물의 항균활성에 관한 연구 (Lee et al., 2009)와 모자반 추출물의 항균활성에 관한 연구 (Yoon, 2010)에서 유기용매 추출물에서는 항균활성이 나타났으나, 물 추출물에서는 항균활성을 보이지 않았다는 결과와 일치하였다. 또한 해조류로부터 생리활성 물질 탐색에 관한 연구에서 시험균 주에 대해 물 추출물이 유기용매 추출물보다 항균활성이 낮게 나타났다는 보고 (Plaza et al., 2010)와도 유사하였다. Plaza et $\mathrm{al}$ 은 에탄올 추출물에는 지방산, 페놀류, 휘발성물질 등의 화합 물이 분리된 반면, 물 추출물에서는 에탄올 추출물보다 상대적 으로 더 적은 휘발성물질과 지방산이 포함되어 있었다고 보고한 바 있다. 지금까지 알려진 해조류 유래 항균물질들은 주로 지방 족화합물 (Proctor, 1957), 브롬화합물 (Xu et al., 2003), chromene 류 (Reddy and Urban, 2009) 및 함황화합물 (Wratten and Faulkner, 1976) 등으로 이들 화합물은 수용성 용매보다 유기 용매에 잘 용출되기 때문에 물 추출물보다 에탄올 추출물에서 더 높은 항균효과를 나타내는 것으로 생각된다. 따라서 본 실험에 사용 한 애기외톨개모자반의 항균활성이 에탄올 추출물에서 나타난 것으로 보아 항균활성을 띄는 물질은 유기용매에 가용성인
소수성 저분자가 주성분일 것으로 생각된다.

Table 2. Antimicrobial activity of Myagropsis yendoi ethanol and water extracts*

\begin{tabular}{ccc}
\hline & Ethanol & water \\
\hline B. subtilis & + & - \\
S. typimurium & - & - \\
\hline
\end{tabular}

*Concentration: $4 \mathrm{mg} / \mathrm{mL}$.

Growth inhibition size of clear zone : -, not detected:

+ , smaller than $1.5 \mathrm{mn}$.

항균활성이 나타난 애기외톨개모자반 에탄올 추출물의 항 균 spectrum을 알아보기 위하여 추가적으로 항균활성을 탐색 하였다. 그 결과, 애기외톨개모자반 에탄올 추출물은 $4 \mathrm{mg} / \mathrm{mL}$ 농도에서 실험에 사용된 그람 양성균인 C. perfringens, L. inoccua, L. monocytogenes 및 S. aureus에 대해 항균활성을 보였으나, 그람 음성균인 E. coli와 S. liquefaciens에 대해서는 항균활성을 나타내지 않았다 (Table 3). 또한 애기외톨개모자 반 에탄올 추출물의 곰팡이와 효모에 대한 항진균활성을 알아 본 결과 (Table 4), C. tropicalis에 대해서는 항진균활성을 나타 내었으나, 나머지 균주에 대해서는 항진균활성을 나타내지 않았다. 이러한 연구 결과는 갈조류의 항균활성에 대한 연구 (Lee et al., 2009)와 모자반 추출물의 항균활성에 관한 연구 (Yoon, 2010)에서 그람 음성균보다 그람 양성균에서 항균효과 가 더 높게 나타났으며, 낮은 항진균활성을 나타내었다는 결 과와 일치하였다. 또한 흑해 갈조류로부터 휘발성 화합물을 분리한 연구 (Kamenarska et al., 2002)에서 5종의 갈조류 추출 물의 항균활성을 측정한 결과, 그람양성균인 S. aureus에 대해 높은 항균활성을 보였다는 결과와도 유사한 경향을 보였으며, 그람 양성균이 그람 음성균에 비해 항균물질에 대한 감수성이 높다는 보고 (Pesando and Caram, 1984)도 일치하였는데, 이는 그람 음성균에는 외부 유입물질에 대한 선택적인 투과 장벽의 역할을 하는 세포외막이 존재하기 때문이라고 알려져 있다 (Nakamura et al., 1991).

Table 3. Antimicrobial activity of Myagropsis yendoi ethanol extract*

C. perfringens $L$. inoccua $L$. monocytogenes S. aureus $E$. coli S. liquefaciens $+$

$+\quad+$

*Concentration: $4 \mathrm{mg} / \mathrm{mL}$.

Growth inhibition size of clear zone : -, not detected: + , smaller than $1.5 \mathrm{mn}$.

Table 4. Antifungal activity of Myagropsis yendoi ethanol extract*

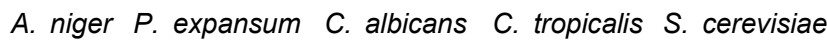

*Concentration: $4 \mathrm{mg} / \mathrm{mL}$.

Growth inhibition size of clear zone : -, not detected:

+ , smaller than $1.5 \mathrm{mn}$. 
Table 5. Minimum inhibitory concentration of extract from Myagropsis yendoi

(Unit : \%)

\begin{tabular}{cccccc}
\hline B. subtilis & C. perfringens $L$. inocca & L. monocytogenes & S. aureus $C$. tropicalis \\
\hline 0.15 & 0.2 & 0.1 & 0.3 & 0.4 & 0.4 \\
\hline
\end{tabular}

애기외톨개모자반 에탄올 추출물의 최소저해농도

애기외톨개모자반 에탄올 추출물에 대해 감수성을 나타내 었던 그람 양성균 5종과 C. tropicalis를 대상으로 MIC test를 실시한 결과 (Table 5), 애기외톨개모자반 에탄올 추출물은 0.15 및 $0.1 \%$ 농도에서 B. subtilis와 L. inoccua의 생육을 억제 하였으며, $0.2 \%$ 농도에서 C. perfringens의 생육을 억제하였다. 또한 $0.3 \%$ 농도에서 L. monocytogenes 의 생육을 억제하였으 며, $0.4 \%$ 농도에서 S. aureus 및 C. tropicalis의 생육을 억제하였 다. 현재 우리나라 식품위생법에는 benzoic acid를 비롯한 13종 의 합성품이 보존료로 사용 허가되어 있다 (Lee et al., 2002). 합성보존료 중 sodium propinate는 0.15-0.3\%에서 정균 또는 살균이 가능한 것으로 보고되었으며 (EI-Shenawy and Marth, 1989), potassium sorbate와 sodium benzoate는 S. aureus에 대해 $\mathrm{pH} 5.5$ 에서 0.52 와 $0.56 \%$, L. monocytogenes에 대해서는 0.23 과 $0.28 \%$ 에서 미생물의 증식을 억제하였다고 보고하였다 (Park and Cha, 2000). 이러한 연구들과 비교해 볼 때 애기외톨개모 자반 에탄올 추출물은 합성보존제와 유사한 항균활성을 보이 지만 정제되지 않은 조추출물임을 고려하면 더 높은 항균활성 을 나타낼 것으로 생각되었다. 따라서 현재 사용되고 있는 방부제나 항균제가 평균적으로 $0.2-0.4 \%$ 정도의 농도의 범위 에서 사용되고 있는 것 (Yang et al., 2009)을 감안하면 애기외 톨개모자반 에탄올 추출물은 안전성이 입증된 천연 물질로써 식품에 적용 가능한 천연 보존제로 이용가능성이 높을 것으로 생각된다.

애기외톨개모자반 에탄올 추출물의 열 및 $\mathrm{pH}$ 안정성

애기외톨개모자반 에탄올 추출물을 식품에 적용하기 위해 서는 가공공정 중 열 및 $\mathrm{pH}$ 변화에도 항균활성이 유지되어야 하므로 애기외톨개모자반 에탄올 추출물의 열 및 $\mathrm{pH}$ 의 변화 에 대한 안정성을 측정하였다. 애기외톨개모자반 에탄올 추출 물의 열 안정성을 알아보기 위하여 $60^{\circ} \mathrm{C}$ 에서 10 분, 30 분 및 60 분, $80^{\circ} \mathrm{C}$ 및 $100^{\circ} \mathrm{C}$ 에서 10 분과 20 분, $121^{\circ} \mathrm{C}$ 에서 15 분간 열처 리한 후 급냉한 애기외톨개모자반 에탄올 추출물을 그람 양성 균 2종과 효모 1 종에 대해 생육저해능을 측정하였다. 그 결과 (Table 6) $121^{\circ} \mathrm{C}$ 에서 15 분간 열처리를 하여도 항균활성에 변화 가 없어 애기외톨개모자반 에탄올 추출물 유래의 항균활성 물질은 열에 비교적 안정한 물질임을 알 수 있었는데, 이는 패, 곰피, 꽈배기모자반, 지충이, 긴불레기말 및 감태를 동일 조건으로 열처리하였을 때 곰피를 제외한 해조류의 항균활성 물질이 안정하였다는 결과와 유사하였다 (Lee et al., 2009). 애기외톨개모자반 에탄올 추출물 유래 항균물질의 $\mathrm{pH}$ 안정성 을 조사하기 위하여 $\mathrm{pH}$ 2, 4, 6, 8 및 10으로 처리하고 24시간 상온에 방치한 후 본래의 $\mathrm{pH}$ 로 중화시켜 실험한 결과 (Table
Table 6. Effect of heat treatment on antimicrobial activity of Myagropsis yendoi ethanol extract*

\begin{tabular}{|c|c|c|c|c|}
\hline & & B. subtilis & L. monocytogenes & C. tropicalis \\
\hline \multicolumn{2}{|l|}{ Untreated } & + & + & + \\
\hline \multirow{3}{*}{$60^{\circ} \mathrm{C}$} & $10 \min$ & + & + & + \\
\hline & $30 \mathrm{~min}$ & + & + & + \\
\hline & $60 \min$ & + & + & + \\
\hline \multirow{2}{*}{$80^{\circ} \mathrm{C}$} & $10 \mathrm{~min}$ & + & + & + \\
\hline & $20 \min$ & + & + & + \\
\hline \multirow{2}{*}{$100^{\circ} \mathrm{C}$} & $10 \mathrm{~min}$ & + & + & + \\
\hline & $20 \min$ & + & + & + \\
\hline $121^{\circ} \mathrm{C}$ & $15 \mathrm{~min}$ & + & + & + \\
\hline
\end{tabular}

*Concentration: $4 \mathrm{mg} / \mathrm{mL}$.

Growth inhibition size of clear zone : -, not detected:

+ , smaller than $1.5 \mathrm{mn}$.

Table 7. Effect of $\mathrm{pH}$ treatment on antimicrobial activity of Myagropsis yendoi ethanol extract*

\begin{tabular}{cccc}
\hline $\mathrm{pH}$ & B. subtilis & L. monocytogenes & C. tropicalis \\
\hline Untreated & + & + & + \\
2 & + & + & + \\
4 & + & + & + \\
6 & + & + & + \\
8 & + & + & + \\
10 & + & + & + \\
\hline
\end{tabular}

*Concentration: $4 \mathrm{mg} / \mathrm{mL}$.

Growth inhibition size of clear zone : -, not detected: + , smaller than $1.5 \mathrm{mn}$.

7), 애기외톨개모자반 에탄올 추출물은 $\mathrm{pH} 2-10$ 의 넓은 범위 에서도 항균활성이 유지되는 것으로 나타났으며, 이는 모자반 에탄올 추출물이 $\mathrm{pH}$ 2-10에서 항균활성이 유지되었다는 결과 (Yoon, 2010)와 일치하였으며, 지충이 에탄올 추출물이 $\mathrm{pH}$ 10 에서 다소 떨어지긴 하였으나 $\mathrm{pH}$ 2-8에서 항균활성이 유지 되었다는 결과 (Lee et al., 2009)와도 유사하였다. 이러한 결과 를 통해 애기외톨개모자반 에탄올 추출물은 $\mathrm{pH}$ 가 낮은 식품 또는 열처리를 하기 힘든 식품을 비롯한 식품의 가공처리에도 적합한 천연 보존료로 유용하게 이용될 수 있을 것으로 기대 되었다.

$$
\text { 사 사 }
$$

본 연구는 2010년 중소기업청의 산학연공동기술개발 지역 사업에 의한 지원에 의해 이루어진 것으로 이에 감사드립니다.

$$
\text { 참고문헌 }
$$

Ahn EY, Shin DH, Baek NI and Oh JA. 1998. Isolation and identification of antimicrobial active substance from Sophora flavescens ait. J Korean Food Sci Technol 30, 672-679.

An AE, Han JS and Shin DH. 1997. Growth inhibition 
of Listeria monocytogenes by pure compound isolated from extract of Morus alba linne bark. Korean J Food Sci Technol 29, 1236-1240

Awad NE, Selim MA, Saleh MM and Matloub AA. 2003. Seasonal variation of the lipoidal matters and hypolipidaemic activity of the red alga Corallina officinalis L. Phytother Res 17, 19-25.

Choi JS, Park HJ, Jung HA, Chung HY, Jung JH and Choi WC. 2000. A cyclohexanonyl bromophenol from the red alga Symphyocladia latiuscula. J Nat Prod 63, 1705-1706.

Chung KS, Kang SY and Kim JY. 2003. The antibacterial activity of garlic juice against pathogenic bacterial and lactic acid bacteria. J Korean Microbiol Biotechnol 31, 32-35.

EI-Shenawy MA, Marth EH. 1989. Behavior of Listeria monocytogenes in the presence of sodium propionate. J Food Microbiol 8, 85-92.

Ferrand C, Marc F, Fritsch P. 2000. Chemical and toxicological studies of products resulting from sorbic acid and methylamine interaction in food conditions. Amino Acids 18, 251-263.

Horie S, Tsutsumi S, Takada Y and Kimura J. 2008. Antibacterial quinone metabolites from the brown alga, Sargassum sagamianum. Bull Chem Soc Jpn 81, 1125-1130.

Hwang JS and Han YS. 2003. Isolation and identification of antimicrobial compound from mokdan bark(Paeonia suffruticosa $\mathrm{A}_{\mathrm{NDR}}$ ). J Korean Soc Food Sci Nutr 32, 1059-1065.

Iwashima M, Mori J, Ting X, Matsunaga T, Hayashi K, Shinoda D, Saito H, Sankawa U and Hayashi T. 2005. Antioxidant and antiviral activities of plastoquinones fromthe brown alga Sargassum micracanthum, and a new chromene derivative converted from the plastoquinones. Biol Pharm Bull 28, 374-377.

Jeong ET, Park MY, Lee EW, Park UY and Chang DS. 1998. Antimicrobial characteristics against spoilage microorganisms and food preservative effect cinnamon(Cinnamomum cassia Blume) bark extract. J Korean Life Science 8, 648-653.

Jo YH, Ok DI and Lee SC. 2009. Antimicrobial characteristics of different parts of Guava against food-borne bacteria. J Korean Soc Food Sci Nutr 38, 1773-1778.

Jung JH and Cho SH. 2003. Effect of Steeping treatment in the natural antimicrobial agent solution on the quality control of processed tofu. J Korean Food
Preserv 10, 41-46.

Kamenarska Z, Dimitrova-Konaklieva S, Stefanov K, Najdenski H, Tzvetkova I and Popov S. 2002. Comparative study of the volatile compounds from Black sea brown algae. Bot Mar 45, 502-509.

Kim JG. 1997. Analysis of problems of food service establishments contributing to food poisoning outbreaks discovered through the epidemiological studies of some outbreaks. J Fd Hyg Safety 12, 240-253.

Kim SJ, Shin JY, Park YM, Chung KM, Lee JH and Kweon DH. 2006. Investigation of antimicrobial activity and stability of Ethanol extracts of licorice root (Glycyrrhiza glabra). J Korean Food Sci Technol 38, 241-248.

Kim YD, Kang SK, Choi OJ, Lee HC, Jang MJ and Shin SC. 2000. Screening of antimicrobial activity of chopi (Zanthoxylum piperitum A.P. DC) extract. J Korean Soc Food Sci Nutr 29, 1116-1122.

Kim JY, Kim KH, Suh HS and Choi WC. 1997. Antiinflammatory effects of new chemical compounds, HS-1580 series(HS-1580, HS-1581, HS-1582). J Life Sci 16, 1181-1187.

Kolanjinathan K, Ganesh P and Govindarajan M. 2009. Antimicrobial activity of ethanol extracts of seaweeds against fish bacterial pathogens. Eur Rev Med Pharmacol Sci 13, 173-177.

Korea food and drug administration(KFDA). 2010. Statistic data base for food poisoning from http://www.kfda.go.kr on June 22.

Kuda T, Kunii T, Goto H, Suzuki T and Yano T. 2007. Varieties of antioxidant and antibacterial properties of Ecklonia kurome products harvested and processed in the Noto Peninsula, Japan. Food Chem 103: 900-905.

Lee $\mathrm{OH}$, Jung SH and Son JY. 2004. Antimicrobial activity of clove extract by extraction solvents. J Korean Soc Food Sci Nutr 33, 494-499.

Lee SE, Park CG, Cha MS, Kim JK, Seong NS, Bang KH and Bang JK. 2002. Antimicrobial activity of essential oils from Mentha arvensis L. var. piperascens Malivaud and Agastache rugosa O. Kuntze on Escherchia coli and Salmonella typhimurium. J Korean Medicinal 10, 206-211.

Lee SY, Kim JH, Song EJ, Kim KBWR, Hong YK, Lim SM and Ahn DH. 2009. Investigation of antimicrobial activity of brown algae extracts and the thermal and $\mathrm{pH}$ effects on their activity. Food Sci Biotechnol 18, 506-512. 
Lee SY, Song EJ, Kim KBWR, Yoon SY, Kim SJ, Lee SJ, Hong YK, Lim SM and Ahn DH. 2009. Antimicrobial activity of ethanol extract form Sargassum thunbergii. J Korean Soc Food Sci Nutr 38, 502-508.

Lee YS, Kim DS, Ryu BH and Lee SH. 1992. Antitumor and immunonodulation effects of seaweeds toward sarcoma-180 cell. J Korean Soc Food Nutr 21, 544-550.

Liu JN, Yoshida Y, Wang MQ, Okai Y and Yamachita UB. 1997. B cell stimulating activity of seaweed extracts. Int J Immunopharmac 19, 135-142.

Nakamura S, Kato AM, Kobayashi K. 1991. New antimicrobial characteristics of lysozyme-dextran conjugate. J Agric Food Chem 39, 647-650.

Mok JS, Kim YM, Kim SH and Chang DS. 1995. Antimicrobial property of the ethanol extract from Salvia miltiorrhiza. J Fd Hyg Safety 10, 23-28.

Pesando, D and B. caram. 1984. Screening of marine algae from the french mediterranean coast for antibacterial and antifungal activity. Bot Mar 27, 381-386.

Park CS and Cha MS. 2000. Comparison of antibacterial activity of green tea extracts and preservation to the pathogenic bacteria. J Korean Soc Food Sci Nutr 13, 36-44.

Plaza M, Santoyo S, Jaime L, Garcia-Blairsy Reina G, Herrero M, Senoran F.J and Ibanez E. 2010. Screening for bioactive compounds from algae. J Pharmaceut Biomed 51, 450-455.

Proctor VW. 1957. Fatty acid composition of lipids in some species of marine algae. Bull Japan Soc Sci Fish 41, 1177-1183.

Reddy P and Urban S. 2009. Metoditerpenoids from the southern Australian marine brown alga Sargassum fallax. Phytochem 70, 250-255.

Sheo HJ. 1999. The antibacterial action of garlic, onion, ginger and red pepper juice. J Korean Soc Food Sci Nutr 28, 94-99.

Su F, Weicai Z, Fan L, Jian Z, Zhirong Y and Qun S. 2010. Antibacterial activity of organic acids in aqueous extracts from pine needles(Pinus massoniana Lamb.). Food Sci Biotechnol 19, 35-41.

Wratten ST and Faulkner DJ. 1976. Cyclic polysulfides from the red alga, Chondria californica. J Org Chem 41, 2465-2467.

Xu N, Fan X, Yan X, Li X, Niu R and Tseng CK. 2003. Antibacterial bromophenols from the marine red alga, Rhodomela confervoides. Phytochem 62, 1221-1224.

Yang HJ, Kim EH, Kang ST and Par SN. 2009. Antibacterial activity of Platycarya strobilacea extract and stability of the extract-containing cream. J Korean Microbial Biothechnol 37, 170-175.

Yoon SY, 2010. Antimicrobial activity of Sargassum fulvellum extract against food spoliage and food poisoning microorganisms. Thesis, Pukyong National University, Busan, Korea, 58.

Yuto K, Miyuki S, Ken-ichiro H, Ryuta T and Hiroshi N. 2009. The novel anti-propionibacterium acnes compound, sagaruran, found in the marine brown alga Sargassum macrocarpum. J Antibiot 62, 259-263.

2010년 9월 30일 접수

2010년 11월 16일 수정

2010년 12월 3일 수리 